\title{
Marginella glabella (Mollusca: Gastropoda: Marginellidae): a new alien species from tropical West Africa established in southern Mediterranean Spain through a new introduction pathway
}

\author{
ÁNGEl A. LUQUE ${ }^{1}$, AgUSTÍn BARRAJÓN ${ }^{2}$, JOSÉ M. REMÓN ${ }^{3}$, DIEGO MORENO ${ }^{3}$ AND LEOPOLDO MORO $^{4}$ \\ ${ }^{1}$ Laboratorio de Biología Marina, Departamento de Biología, Universidad Autónoma, C/Darwin, 2, 28049 Madrid, Spain, ${ }^{2}$ Nuzas, 14; \\ 29010 Málaga, Spain, ${ }^{3}$ Agencia de Medio Ambiente y Agua de Andalucía, Parque Comercial Málaga Nostrum, Edif. Galia Center, \\ C/ Jaén, 9, $3{ }^{\mathrm{a}}$ pl., 29004 Málaga, Spain, ${ }^{4}$ Servicio de Biodiversidad, Gobierno de Canarias, C/José de Zárate y Penichet, 5 bajo, 38071 \\ Santa Cruz de Tenerife, Spain
}

\begin{abstract}
We report the occurrence in the inner fishing port of the Málaga harbour (southern Spain) of an established population of the gastropod Marginella glabella, native on West African Atlantic coasts of Morocco to Senegal and also present at the Canary Islands. This is the third gastropod species with a tropical Atlantic origin found as an established population in the Mediterranean. In spite of its presumably scarce self-dispersal ability due to its direct development, it should be considered an invasive species since it is potentially able to spread out from the area currently occupied and preys voraciously on autochthonous gastropods. It is suggested that this species was introduced during the 199os as within port discarded by-catch of Málaga-based trawlers, which at that time were fishing on the Atlantic coast off Morocco and the Canary-Saharian bank.
\end{abstract}

Keywords: Marginella glabella, Gastropoda, West Africa, Mediterranean, southern Spain, alien species, new introduction pathway

Submitted 16 December 2011; accepted 22 December 2011

\section{INTRDDUCTIDN}

Molluscs are relatively well known marine invertebrates from both taxonomic and biogeographical points of view, and represent a significant proportion of fauna in terms of diversity and biomass in any marine benthic community. Shelled molluscs are by far the most diverse and abundant and the persistence of shells after the animal dies make them easily detectable for long periods. This persistence, together with natural or man-mediated shells movement or transport may induce false records both for native or alien species. Many molluscs have planktonic larval stages (planktotrophic or nonplanktotrophic), which favour respectively a more or less high dispersal ability and wide distribution areas, whereas others have a so-called direct development, hatching as small individuals and usually settling down in the same area as their parents; the latter have restricted dispersal capacities and usually have smaller distribution ranges.

A total of 135 alien species of marine gastropods were recorded from the Mediterranean Sea, 112 (83\%) of them originally from the tropical Red Sea or the Indo-Pacific. Most of these latter species migrated via the Suez Canal (lessepsian immigrants) and are still mainly confined to the

Corresponding author:

Á.A. Luque

Email: angel.luque@uam.es
Eastern Basin (Gofas \& Zenetos, 2003; Streftaris et al., 2005; Zenetos et al., 2010). The Western Mediterranean has a low incidence of alien gastropods, with 17 species (Zenetos et al., 2010); only two of them (Favorinus ghanensis Edmunds, 1968 and Mitrella psilla (Duclos, 1846)) were introduced through shipping from tropical West Africa (Ben Souissi et al., 2004; Antit et al., 2010). Most records of species with tropical West African affinity in the Western Mediterranean Basin are not true aliens, but species whose range encompass at least part of the Alboran Sea since historical times (Gofas \& Zenetos, 2003; Antit et al., 2010) and therefore should be considered native (Moreno, 2010; Zenetos et al., 2010). Except for the recent record of the South African nudibranch Godiva quadricolor (Barnard, 1967) (also recorded from Western Australia and the central Mediterranean) for the Algeciras harbour (Cervera et al., 2010), no other alien species were found in the Alboran Sea (Zenetos et al., 2010).

The Málaga province (Spain) is situated at the westernmost part of the Alboran Sea, close to the Strait of Gibraltar, which is considered a major hot spot of biodiversity (Coll et al., 2010; Zenetos et al., 2010; CIESM, 2011). The molluscan fauna of this strategic area as a means to detect inflow of Atlantic aliens is rather well known, and this area is also well covered by different marine research institutions. However, the presence of a conspicuous species such as the West African gastropod Marginella glabella (Linné, 1758), whose 
first occurrence as an established alien species in the Mediterranean Sea we report here, has apparently been overlooked for years.

\section{MATERIALS AND METHDDS}

Samples were hand-picked by SCUBA diving in the fishing port of the Málaga harbour $\left(36^{\circ} 42.608^{\prime} \mathrm{N} 04^{\circ} 25.362^{\prime} \mathrm{W}\right.$; Datum ETRS89), on 1 April and 10 December 2009, and 24 November 2010, at depths from o (low tide) to $9 \mathrm{~m}$; water temperature in December 2009 sampling was $13^{\circ} \mathrm{C}$, and $19^{\circ} \mathrm{C}$ in November 2010. The sampled area was the trawlers dock, where fishing catches are discharged and by-catch eventually discarded and thrown to the water. Two transects of $25 \times 4 \mathrm{~m}$ were covered to estimate density from 3.5 to $6 \mathrm{~m}$ depth. Specimens were measured in situ.

Five specimens collected in November 2010 (four adults and a $39 \mathrm{~mm}$ subadult with no thickened outer lip) were preserved in $70 \%$ ethanol, and four adult specimens (one male and three females) collected alive in December 2009, were maintained during 2010 in a marine aquarium.

\section{RESULTS}

Numerous specimens of Marginella glabella were observed on the bottom of the fishing port, some of them crawling but most hidden or half-buried in daylight hours, and not associated with carrion or feeding; this species shows chiefly a nocturnal activity. Only one young specimen was found on the pier walls at low tide. From 35 measured specimens, $72.2 \%$ were adults with a fully thickened outer lip, reaching a maximum shell length of $44 \mathrm{~mm}$; minimum length of a young specimen was $8 \mathrm{~mm}$; mean shell length of sample was $32.75 \mathrm{~mm}$ (SD 9.74). Shells were homogeneous in colour pattern and frequently showed black coloured areas due to contact with anoxic muddy bottom (Figure 1). Mean density estimated in transects was 0.35 individuals $/ \mathrm{m}^{2}$, with maxima of $4-6$ individuals $/ \mathrm{m}^{2}$.

The habitat at the sampled point corresponds to a severely polluted harbour area. Water column is extremely turbid (visibility $2-5 \mathrm{~m}$ ), with a high number of particles in suspension and greenish colour due to chlorophyll. Floating solid

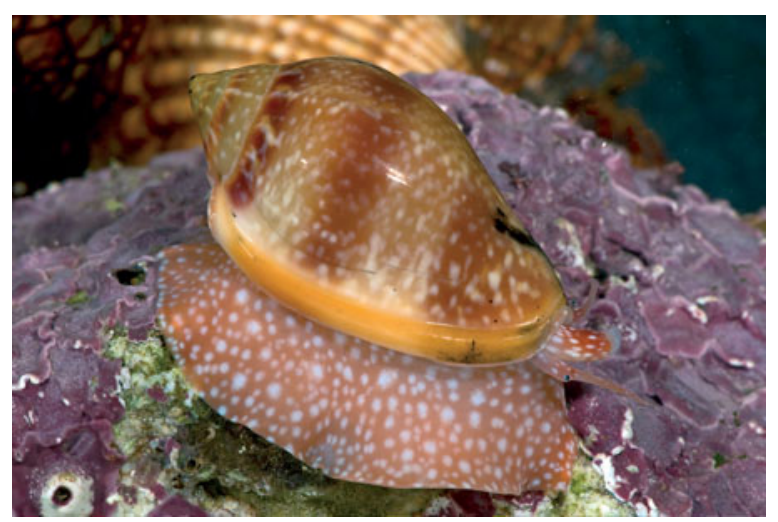

Fig. 1. Marginella glabella: specimen of $37 \mathrm{~mm}$ from the fishing port of the Malaga harbour showing black coloured areas, due to contact with anoxic muddy bottom. debris, dead fish and fuel spots are common on the water surface. Pier walls are covered at intertidal level by a discontinuous belt of mussels (Mytilus galloprovincialis Linné, 1758), followed down by a fringe of the phaeophyte Stypocaulon scoparium (Linné) Kützing, 1843, some colonies of the ascidian Clavelina lepadiformis (Müller, 1776) and small chlorophycean algae. Other common species are the ascidians Styela plicata (Lesueur, 1823) and Phallusia mammillata (Cuvier, 1815), the sabellid polychaete Sabella spallanzanii (Gmelin, 1791) and the crustacean decapod Pachygrapsus marmoratus (Fabricius, 1787). The compacted muddy bottom is covered by abundant solid artificial waste (ropes, pieces of nets, tyres, diverse plastic, and metallic and glass objects) and organogenic debris from trawlers discards. The latter are mainly molluscan shells (Acanthocardia tuberculata (Linné, 1758), Callista chione (Linné, 1758), Pecten maximus (Linné, 1758), Mytilus galloprovincialis and Cymbium olla (Linné, 1758) are the most common), rotten fish and other invertebrate remains. Some discarded invertebrates remain alive, like the pennatulaceans Veretillum cynomorium (Pallas, 1766), Pennatula rubra (Ellis, 1761) and Pteroeides spinosum (Ellis, 1764) and the alcyonarian Alcyonium palmatum Pallas, 1766; the pagurid decapod Dardanus arrosor (Herbst, 1796) with its symbiotic anemone Calliactis parasitica (Couch, 1838) is common feeding on this carrion. The most abundant benthic species are the ascidian Phallusia mammillata, the echiurid Bonellia viridis Rolando, 1821 and the actiniarian Anemonia sulcata (Pennant, 1777). The sabellid Sabella spallanzanii, the sea urchins Arbacia lixula (Linné, 1758) and Paracentrotus lividus (Lamarck, 1816), the starfish Marthasterias glacialis (Linné, 1758) and the decapod Palaemon elegans Rathke, 1837 are also common. The most abundant molluscs are the gastropods Nassarius reticulatus (Linné, 1758) and Cerithium vulgatum Bruguière, 1792; Ocenebra erinaceus (Linné, 1758), Calyptraea chinensis (Linné, 1758) and the bivalve Anomia ephippium Linné, 1758 are also frequent.

Specimens of $M$. glabella held in aquaria were sedentary and remained immobile for days at the same place, partially or totally buried in sand except for the distal part of the siphon. As in their habitat, they were more active at night. They were observed feeding on diverse gastropods, dead commercial fish and even a live fish (Lepadogaster candolii Risso, 1810). When feeding on gastropods, M. glabella extends its long pleurembolic proboscis under the shell; the prey seems to be paralysed and then partially involved with foot (Figure 2). The specimens in our aquarium preyed on Phorcus richardi (Payraudeau, 1826), Nassarius reticulatus, Nassarius mutabilis (Linné, 1758) and Coralliophila brevis (de Blainville, 1832). Time of feeding varied between 45 minutes ( $P$. richardi) and 2 hours (Nassarius mutabilis). No mating or spawns were observed during observation time (one year), even at temperatures of $25^{\circ} \mathrm{C}$.

\section{DISCUSSIDN}

Marginella glabella (Linné, 1758) is an easily recognizable, medium sized (up to $50 \mathrm{~mm}$ in length) species, with a brightly coloured shell. It was originally described from West Africa (type locality: 'in O. Africano'). The oldest available and precise record for this species seems to be that of Adanson (1757, as La Porcelaine) from Gorée (Senegal), to whose 


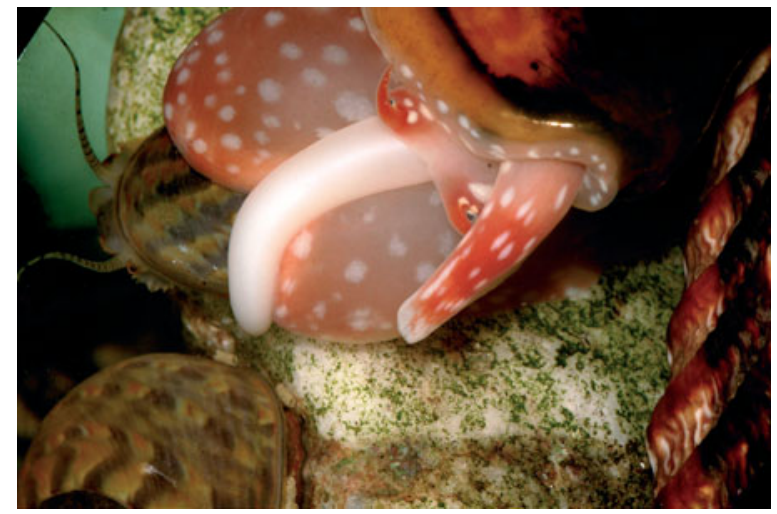

Fig. 2. Marginella glabella: specimen of $39 \mathrm{~mm}$ from the fishing port of the Malaga harbour with everted proboscis preying in aquarium on Phorcus richardi.

illustration Linné (1767) referred in the twelfth edition of Systema Naturae. Linnean types seem to be lost (Dodge, 1955), but one specimen probably belonging to this species was recorded by Wallin (2001) from Linnean collection types housed at the Uppsala University Zoological Museum (no locality given).

The known distribution of Marginella glabella includes the West African coast from Morocco (El Jadida and Essaouira) south to Senegal and Guinea, and the Canary Islands (Pallary, 1920; Nicklès, 1950; Knudsen, 1956; PasteurHumbert, 1962; Lewy, 1975; Talavera, 1975; Altimira, 1978b; Pérez \& Moreno, 1991; Goud \& Neefs, 1996; Ardovini \& Cossignani, 2004; Hernández et al., 2011). Rolán (2005) denied the presence of this species in the Cape Verde Islands, suggesting that previous records were probably based on specimens brought by Cape Verdean fishermen from West African fisheries. According to Gofas \& Zenetos (2003), Marginella glabella is established in Atlantic Morocco and Sahara and is liable to occur in the Mediterranean Sea, but it has not been recorded so far, except for the questionable record of hermit-crabs that inhabited shells trawled from Marbella (Málaga) at $100 \mathrm{~m}$ depth (Spada \& Maldonado, 1974).

In its natural habitat Marginella glabella is a common species living from intertidal to subtidal soft bottoms both with or without rocks and stones, usually in sheltered areas at lower depths (McAndrew, 1853; Dautzenberg, 1891; Pérez \& Moreno, 1991; authors, personal observations), or in sand of Cymodocea nodosa meadows (Espino et al., 2008; authors, personal observations). Living specimens are found from the intertidal zone down to $90 \mathrm{~m}$ depth, but seem to be more frequent in the upper third of this range $(0-30 \mathrm{~m})$; shells are found down to 200-300 m (Dautzenberg, 1910; Knudsen, 1956; Pasteur-Humbert, 1962; Talavera, 1975; Altimira, 1978a, b; Goud \& Neefs, 1996; authors, personal observations). In the Canary Islands this species shows nocturnal activity both in Cymodocea meadows and transition zones between sand and rocky bottoms (authors, personal observations).

True Mediterranean established alien gastropods of West African origin, i.e. species not previously recorded in the Mediterranean, man-introduced and fulfilling criteria for established species (European Commission, 2004; Zenetos et al., 2010) are known up to now by two examples: Mitrella psilla and Favorinus ghanensis from the Tunisian coasts (Antit et al., 2010; Zenetos et al., 2010). Thus, this is the third record of a gastropod with a tropical West African origin forming an established population in the Mediterranean, and the first record in the Alboran Sea.

Sinum bifasciatum (Récluz, 1851) is also a West African gastropod well-established on the Málaga coast, but it is apparently self-introduced by active dispersal and previously recorded since the 19th Century from the Balearic Islands and southern Italy (Rueda \& Gofas, 2000; Gofas \& Zenetos, 2003); thus, it might be considered native, according to Zenetos et al. (2010). Euspira grossularia (Marche-Marchad, 1957) also seems to be well-established (authors, personal observations) and self-introduced in the Alboran Sea, but its classification as native species is doubtful due to its relatively recent description and lower-shelf habitat. Other West African records from the Alboran Sea by Maldonado (1973) and Spada \& Maldonado (1974), like Bolinus cornutus (Linné, 1758), Nassarius wolffi (Knudsen, 1956) or Nassarius pinguis (Adams A., 1853), should be considered questionable (sensu Zenetos et al., 2010) and were mainly based on empty or hermit-crab inhabited shells, probably introduced by trawler boats coming back from West African fisheries to their Mediterranean base-ports.

Marginella glabella is a gonochoric species, as are other known marginellids (Coovert \& Coovert, 1995). Purseshaped egg capsules are found fixed under stones by a short stalk; they contain a single young specimen close to hatching (Boyer, 2009; L. Moro, personal observation at the Canary Islands). All known marginellids show paucispiral protoconch indicating direct development, and crawling young snails hatch from the capsule in all species studied (Coovert, 1986; Ponder, 1998). Lack of a planktonic larval phase prevents such a dispersal means for Marginella glabella. Rafting dispersal of adults, juveniles and/or egg capsules is an alternative means of covering long distances for invertebrates without planktonic larvae, and it is frequent in bays or lagoons and facilitated by substrata of biotic origin, like seagrasses or algae (Thiel \& Haye, 2006). However, rafting in Marginella glabella must also be disregarded due to heavy individuals and egg capsules usually fixed under stones. Even if some egg capsules were eventually fixed to seagrasses or algae, the main surface current flows southwards along the North African coast from latitudes north (Gyory et al., 2011) of the northernmost record of this species (El Jadida, Morocco). Direct development also prevents transport in ballast water, and the habitat of the species also makes the possibility of egg capsules fixed to the hull of ships not feasible.

During the 1980 os and 1990s, the Málaga port was the base of a fleet of trawlers (about 10 in 1990) usually fishing from South Morocco to the Western Sahara (Canary-Saharian Bank) up to the end of 1999, when fishing activity of this fleet ceased. Marginella glabella is a common species in this area, and specimens mixed with other fishing remains were easy to find in those years in trawler decks or nets left to repair in the Málaga fishing port (authors, personal observations). From the northernmost fishing area in Morocco, trawlers delayed about 20 hours in arriving to their base (Rafael Arias, personal communication). Therefore, it is probable that Marginella glabella arrived to the Málaga fishing port either as young or adult specimens still alive, or as spawns fixed to stones or other objects and then were discarded as by-catch within the port. As far as we know, this kind of 
shipping transport represents a new introduction pathway of alien species in the Mediterranean. The occurrence of M. glabella in the Canary Islands could be due to the same introduction pathway, but further research and genetic studies of populations from West Africa, Malaga and the Canary Islands are needed to give more information about the geographical origin and genetic diversity of the latter two populations.

This tropical species seems to be well-adapted to low winter temperatures in the Málaga port and also to heavily polluted waters and hard harbour conditions, showing an established and apparently thriving population more than ten years after its presumable date of introduction. Once again, harbours prove to be a focus for established populations of alien species (Zenetos et al., 2010). Marginella glabella should be considered an invasive species (sensu Zenetos et al., 2010), since it is potentially able to spread widely from the area currently occupied and preys voraciously on autochthonous gastropods. Although it seems to be restricted to the inner fishing port of the Málaga harbour, we strongly recommend to the environmental authorities of Andalusia to establish a monitoring programme to test a possible spread of this population outwards of this area, and to disregard the occurrence of Marginella glabella in other fishing ports (Fuengirola, Marbella and Estepona) from trawlers that fished at that time in Morocco and the CanarySaharian Bank.

\section{ACKNDWLEDGEMENTS}

We thank Rafael Arias Portales, fishing net repairer and established trawlerman in Morocco for useful information; Antonio de la Linde (Agencia de Medio Ambiente y Agua de Andalucía) and Silvia Maldonado for help with sampling; Luis Manuel Noain and Nicolas Cristelli (Professional Diving School of the Málaga Port) for information and diving facilities; and Marta Pola and Serge Gofas for useful comments. Eduardo Fernández Tabales (Consejería de Medio Ambiente, Junta de Andalucía) facilitated the collaboration with the Programme of Management and Conservation of the Marine Environment of the Consejería de Medio Ambiente (Junta de Andalucía).

\section{REFERENCES}

Adanson M. (1757) Histoire naturelle du Sénégal. Coquillages. Paris: Claude-Jean-Baptiste Bauche.

Altimira C. (1978a) Avance sobre algunos moluscos colectados por la expedición 'Atlor VII'. Resultados Expediciones Científicas B/O Cornide 7, 169-171.

Altimira C. (1978b) Moluscos marinos de las costas del NW de África (expedición 'Atlor VII'). Resultados Expediciones Científicas B/O Cornide 7, 173-193.

Antit M., Gofas S. and Azzouna A. (2010) A gastropod from the tropical Atlantic becomes an established alien in the Mediterranean. Biological Invasions 12, 991-994.

Ardovini R. and Cossignani T. (2004) West African seashells. Ancona, Italy: L'Informatore Piceno.

Ben Souissi J., Zaouali J., Rezig M., Bradá M.N., Quignard J.P. and Rudman B. (2004) Contribution à l'étude de quelques récentes migrations d'espèces exotiques dans les eaux tunisiennes. Rapports de la Commission Internationale pour l'Exploration Scientifique de la Mer Méditerranée 37, 312.

Boyer F. (2009) On the egg capsule of Marginella glabella (Linné, 1758). Iberus 27, 99-102.

Cervera J.L., Tamsouri N., Moukrim A. and Villani G. (2010) New records of two alien opisthobranch molluscs from the north-eastern Atlantic: Polycera hedgpethi and Godiva quadricolor. Marine Biodiversity Records 3, e51, doi:10.1017/S1755267210000102.

CIESM (2011) Marine Peace Parks in the Mediterranean-a CIESM proposal. In Briand F. (ed.) CIESM Workshop Monographs, No. 41. Monaco: CIESM, pp. 1-128.

Coll M., Piroddi C., Steenbeek J., Kaschner K., Ben Rais Lasram F., Aguzzi J., Ballesteros E., Bianchi C.N., Corbera J., Dailianis T., Danovaro R., Estrada M., Froglia C., Galil B.S., Gasol J.M., Gertwagen R., Gil J., Guilhaumon F., Kesner-Reyes K., Kitsos M.-S., Koukouras A., Lampadariou N., Laxamana E., López-Fé de la Cuadra C.M., Lotze H.K., Martin D., Mouillot D., Oro D., Raicevich S., Rius-Barile J., Saiz-Salinas J.I., San Vicente C., Somot S., Templado J., Turon X., Vafidis D., Villanueva R. and Voultsiadou E. (2010) The biodiversity of the Mediterranean Sea: estimates, patterns, and threats. PLOS ONE 5, e11842, doi:10.1371/ journal.pone.0011842.

Coovert G.A. (1986) A review of marginellid egg capsules. Marginella Marginalia 1, 13-19.

Coovert G.A. and Coovert H.K. (1995) Revision of the supraspecific classification of marginelliform gastropods. Nautilus 109, 43-110.

Dautzenberg P. (1891) Voyage de la goelette Melitta aux Canaries et au Sénégal (1889-1890). Mollusques testacés. Mémoires de la Société Zoologique de France 4, 16-65.

Dautzenberg P. (1910) Contribution à la faune malacologique de l'Afrique occidentale. Actes de la Société Linneénne de Bourdeaux 54, $47-220$.

Dodge H. (1955) A historical review of the mollusks of Linnaeus. Part 3. The genera Bulla and Voluta of the class Gastropoda. Bulletin of the American Museum of Natural History 107, 1-158.

Espino F., Tuya F., Blanch I. and Haroun R.J. (2008) Los sebadales en Canarias. Oasis de vida en los fondos arenosos. Universidad de Las Palmas de Gran Canaria: BIOGES.

European Commission (2004) Environment Directorate-General LIFE Focus I Alien species and nature conservation in the EU. The role of the LIFE program. Luxembourg: Office for Official Publications of the European Communities. Available from http://ec.europa.eu/ environment/life/publications/lifepublications/lifefocus/documents/ alienspecies_en.pdf (accessed 21 December 2011).

Gofas S. and Zenetos A. (2003) Exotic molluscs in the Mediterranean basin: current status and perspectives. Oceanography and Marine Biology: an Annual Review 41, 237-277.

Goud J. and Neefs J. (1996) The larger marginelliform gastropods (Cystiscidae and Marginellidae) collected during the CANCAP and Mauritania expeditions in the south-eastern part of the North Atlantic Ocean. The genera Persicula, Prunum, Dentimargo, Marginella and Glabella. Vita Marina 43, 25-50.

Gyory J., Mariano A.J. and Ryan E.H. (2011) The Canary Current. Available from http://oceancurrents.rsmas.miami.edu/atlantic/ canary.html (accessed 21 December 2011).

Hernández J.M., Rolán E., Swinnen F. Gómez R. and Pérez J.M. (2011) Moluscos y conchas marinas de Canarias. Hackenheim, Germany: ConchBooks.

Knudsen J. (1956) Marine prosobranchs of tropical West Africa (Stenoglossa). Atlantide Report 4, 7-110. 
Lewy Z. (1975) Mollusks distribution on the Atlantic continental shelf off southern Spanish Sahara, West Africa. Meteor Forschungsergebnisse (C) 21, 52-60.

Linné C.V. (1767) Systema naturae per regna tria naturae, secundum classes, ordines, genera, species, cum characteribus, differentiis, synonymis, locis. Tomus I, Pars II. Editio duodecima, reformata. Holmiae [Stockholm]: Laurenti Salvii.

Maldonado A. (1973) Segnalazione di un Nassariidae nuovo per il Mediterraneo. Conchiglie 9, 231-234.

McAndrew R. (1853) On the geographical distribution of testaceous Mollusca in the north-east Atlantic and neighbouring seas. Proceedings of the Literary and Philosophical Society of Liverpool 8, $8-56$.

Moreno D. (2010) Flora y fauna alóctona del medio marino andaluz. In Cobos F.J. and Ortega F. (eds) Especies exóticas invasoras en Andalucía. Talleres provinciales 2004-2006. Seville: Consejería de Medio Ambiente, Junta de Andalucía, pp. 214-229.

Nicklès M. (1950) Mollusques testacés marins de la côte occidentale d'Afrique. Paris: Paul Lechevalieur.

Pallary P. (1920) Exploration scientifique du Maroc organisée par la Société de Géographie de Paris et continuée par la Société des Sciences Naturelles du Maroc. Deuxième fascicule. Malacologie (1912). Rabat and Paris: Larose.

Pasteur-Humbert C. (1962) Les mollusques marins testacés du Maroc. Catalogue non critique. I. Les Gastéropodes. Travaux de l'Institut Scientifique Chérifiensérie Zoologie 23, 1-244.

Pérez J.M. and Moreno E. (1991) Invertebrados marinos de Canarias. Las Palmas de Gran Canaria: Ediciones del Cabildo Insular de Gran Canaria.

Ponder W.F. (1998) Family Marginellidae. In Beesley P.L., Ross G.J.B. and Wells A. (eds) Mollusca: the southern synthesis. Fauna of Australia. Volume 5. Melbourne: CSIRO Publishing, pp. 831-841.

Rolán E. (2005) Malacological fauna from the Cape Verde Archipelago. Hackenheim, Germany: ConchBooks.

Rueda J.L. and Gofas S. (2000) Sinum bifasciatum (Récluz, 1851) (Gastropoda: Naticidae) confirmed in Mediterranean fauna. Journal of Conchology 36, 81-82.
Spada G. and Maldonado A. (1974) Nota preliminare sulle specie di molluschi a diffusione prevalentemente atlantica e presenti anche nel Mediterraneo nel mare di Alboran. Quaderni della Civica Stazione Idrobiologica di Milano 5, 51-69.

Streftaris N., Zenetos A. and Papathanassiou E. (2005) Globalisation in marine ecosystems: the story of nonindigenous marine species across European seas. Oceanography and Marine Biology: an Annual Review $43,419-453$.

Talavera F.G. (1975) Moluscos de sedimentos de la plataforma continental de Mauritania. Boletín del Instituto Español de Oceanografía 192, $1-18$.

Thiel M. and Haye P.A. (2006) The ecology of rafting in the marine environment. III. Biogeographical and evolutionary consequences. Oceanography and Marine Biology: an Annual Review 44, 323-428.

Wallin L. (2001) Catalogue of type specimens. 4. Linnean specimens. Uppsala University, Museum of Evolution, Zoology section. Available from http://www.evolutionsmuseet.uu.se/samling/UUZMo4_ Linnaeus.pdf (accessed 21 December 2011).

and

Zenetos A., Gofas S., Verlaque M., Cinar M.E., García Raso J.E., Bianchi C.N., Morri C., Azzurro E., Bilecenoglu M., Froglia C., Siokou I., Violanti D., Sfriso A., San Martín G., Giangrande A., Katagan T., Ballesteros E., Ramos-Esplá A., Mastrototaro F., Ocaña O., Zingone A., Gambi M.C. and Streftaris N. (2010) Alien species in the Mediterranean Sea by 2010. A contribution to the application of European Union's Marine Strategy Framework Directive (MSFD). Part I. Spatial distribution. Mediterranean Marine Science $11,381-493$.

\section{Correspondence should be addressed to:}

\section{Á.A. Luque}

Laboratorio de Biología Marina

Departamento de Biología

Universidad Autónoma, C/ Darwin, 2, 28049 Madrid, Spain email: angel.luque@uam.es 